\title{
ANALYSIS OF HABITAT USE, ACTIVITY, AND BODY CONDITION SCORES OF PRZEWALSKI'S HORSES IN HORTOBAGY NATIONAL PARK, HUNGARY
}

\author{
Viola Kerekes ${ }^{1}$, Katalin Ozogány ${ }^{2}$, István Sándor ${ }^{3}$, Zsolt Vegvari², Csilla Czető ${ }^{2}$, \\ Bettina Nyírő ${ }^{4}$, Timea Szabados ${ }^{1}$, Lajos Széles², Zoltán Barta² \\ ${ }^{1}$ Hortobagy National Park Directorate, Hungary \\ e-mail:kerekesviola@hnp.hu \\ ${ }^{2}$ Debrecen University, Hungary \\ e-mail:katalin.ozogany@gmail.com,szelesl@med.unideb.hu,barta.zoltan@science.unideb.hu \\ ${ }^{3}$ Budapest Zoo and Botanical Garden, Hungary \\ e-mail:afiumvet@gmail.com \\ ${ }^{4}$ Government Office of Hajdú-Bihar County, Hungary \\ e-mail:nyiro.bettina@hajdu.gov.hu
}

Received: 10.04.2019. Revised: 27.04.2019. Accepted: 05.05.2019.

\begin{abstract}
A founder population of Przewalski's horses (Equus ferus przewalskii) was set free in a semi-reserve called Pentezug in the Hortobagy National Park (Hungary) in 1997. Beside the Przewalski's horses reconstructed aurochs (Bos taurus taurus) were bred as well in the $24.5-\mathrm{km}^{2}$ large area. Both species reproduced successfully in this steppe reserve, which was once the homeland of their distant ancestors. The number of large grazers has grown so quickly that different strategies of population control had to be implemented for reconstructed aurochs and horses in 2007 and 2013, respectively. The activity, habitat use, and body condition of Przewalski's horses were monitored regularly throughout the 22 years. We detected seasonal changes in the activity of the horses but the proportions of the main activity types were similar in two distant time periods. In contrast, habitat use and body condition scores for the horses showed remarkable differences between early vs. late years of the project, implying that horses were forced to use non-preferable areas and their condition was worsened in parallel with the increased population density of the large grazers. During the cold spring in 2018, there was a massive loss of both horses and cattle. These observations suggest that limited food sources could lead to changes in habitat use and/or worse body condition and a greater death rate in extreme weather conditions. In summary, strict birth control measures must be implemented in dense Przewalski's horse populations, and the habitat use and body conditions must be monitored to balance the population size and carrying capacity of the areas.
\end{abstract}

Key words: Bos taurus taurus, carrying capacity, Equus ferus przewalskii, large grazers, population control, Pentezug Reserve, reconstructed aurochs, semi-reserve

\section{Introduction}

In the Holocene period, wild horses (Equus ferus Boddaert, 1785) inhabited both Europe and Asia (Vörös, 1987). Their descendant subspecies disappeared from the wild, first in Europe and then in Asia in the 1960s (Sommer et al., 2011). Fortunately, Przewalski's horses (Equus ferus przewalskii Poliakov, 1881), a Mongolian subspecies, survived in captivity and their descendants can be found in zoos and in the wild again due to various projects (Bouman \& Bouman, 1994). Reintroduction projects were started in China (Xinjiang Wild Horse Breeding Centre and Kalamaili Mountain National Park) and Mongolia (Khustain Nuruu National Park and Great Gobi B Strictly Protected Area) in 1985 and 1991, respectively (Wakefield et al., 2002; King, 2005; Walzer et al., 2012; Xia et al., 2014).
Besides the reintroduction projects in Mongolia and China, many closed natural conservation areas are home to Przewalski's horses all over the world. The herd in the Pentezug Reserve (Hortobágyi National Park, Hungary) represents the largest population of Przewalski's horses in Europe. The project, which was started in 1997, was coordinated, supervised, and financed by the Hortobágy National Park (hereinafter HNP) and the Cologne Zoo (Germany). Horses and a hardy breed of domestic cattle (Bos taurus Linnaeus, 1758), called Heck cattle or reconstructed aurochs, were kept together in the area surrounded by an electric fence. The Heck cattle, which have been used for landscape management in several other regions in Europe (Lorimer \& Driessen, 2013) are phenotypically similar to the extinct aurochs (Bos taurus primigenius Bojanus, 1827), which once inhabited 
the Hungarian Steppe. The aim of this project was to create an alternative grazing ecosystem with minimal human intervention compared to grazing livestock. The Pentezug Reserve is part of the steppe vegetation of HNP and provides adequate grass species and water supply (marshes and canals) for large grazers. However, apex predators of large herbivores are missing.

Equidae have a cecal digestion system (Janis, 1976), which means that the food goes through their digestion system quickly and they can live on vegetation with low nutritional content. As a consequence, horses choose habitats based on a green plant content (Duncan, 1983; King, 2002) and have to graze more in winter when the nutritional content of vegetation is lower (Boyd \& Bandi, 2002; Souris et al., 2007). With a growing density of large grazers, horses might have to use areas that are not optimal (Beest et al., 2014), affecting their body condition.

In this study, we describe our observations on habitat use, activity, and body condition over several years. Seasonal changes and changes occurring over larger time intervals, parallel to the population growth, can be distinguished. The results, accumulated during more than 20 years, contribute to our understanding of the activity and habitat use of Przewalski's horses and may facilitate herd management or novel project designs.

\section{Material and Methods \\ Study area}

The HNP, established in 1972 as the first national park in Hungary, is located in the Eastern part of the country, $150 \mathrm{~km}$ from Budapest. The research area, called Pentezug Reserve (24.5 $\mathrm{km}^{2}$ ), can be found in the middle of the HNP at $47.5175 \mathrm{~N}, 21.092778 \mathrm{E}$. The climate is dry continental with $550 \mathrm{~mm}$ annual precipitation. Four seasons can be differentiated, where the winter is cold and dry with a minimum temperature of $-15^{\circ} \mathrm{C}, 20-40$ day snow cover $(2-15 \mathrm{~cm})$ and the summer is hot with a maximum temperature of $+35^{\circ} \mathrm{C}$. There are moderate temperatures and more rainfall in autumn and spring. The reserve is part of the continental alkali grassland region that is characterised by salt and water content of the soil and the natural floods. The groundwater, which is rich in different salts and close to the surface, easily evaporates when the weather is hot. As a consequence, these salts accumulate in the upper soil level (Török et al., 2012). Due to these phenomena, these grasslands are not suitable for agricultural utilisation and have been used as pastures for centuries (Molnár, 2014). We can differentiate eight habitat types in the Pentezug Reserve with different plant associations showed in Table 1 (Deák et al., 2014a,b,c).

Table 1. Habitat types in Pentezug Reserve (Hungary)

\begin{tabular}{|c|c|c|c|c|}
\hline $\begin{array}{l}\text { Habitat } \\
\text { Type }\end{array}$ & Association & Characteristics & $\begin{array}{c}\text { Characteristic plant } \\
\text { species }\end{array}$ & $\begin{array}{l}\text { Habitat area in } \\
\text { Pentezug }\left(\mathrm{km}^{2}\right)\end{array}$ \\
\hline Forest & Planted oak forest & along the river & Quercus robur L. & 0.315887 \\
\hline Alkali marsh & $\begin{array}{l}\text { Bolboschoenetum } \\
\text { maritimi }\end{array}$ & $\begin{array}{l}\text { shallow water cover, considerable salt } \\
\text { content both in the soil and water }\end{array}$ & $\begin{array}{l}\text { Bolboschoenus maritimus } \\
\text { (L.) Palla }\end{array}$ & 2.207703 \\
\hline Reed bed & $\begin{array}{l}\text { Phragmittetum } \\
\text { communis }\end{array}$ & deep water cover & $\begin{array}{l}\text { Phragmites australis } \\
\text { (Cav.) Trin. ex Steud. }\end{array}$ & 0.712105 \\
\hline Weed & $\begin{array}{l}\text { Onoprodetum acanthi, } \\
\text { Hordaetum hystricis }\end{array}$ & $\begin{array}{l}\text { on former livestock farms, high soil } \mathrm{N} \\
\text { and } \mathrm{P} \text { content }\end{array}$ & $\begin{array}{l}\text { Onopordium acanthium } \\
\text { L., Hordeum hystrix Roth. }\end{array}$ & 0.277978 \\
\hline Alkali steppe & $\begin{array}{l}\text { Artemisio santonici- } \\
\text { Festucetum pseudovinae }\end{array}$ & $\begin{array}{l}\text { short grass on solonetz soil, moderate } \\
\text { humus content, low to moderate salt } \\
\text { content in the deeper soil layers }\end{array}$ & $\begin{array}{l}\text { Festuca pseudovina Hack } \\
\text { ex Wiesb., Artemisia } \\
\text { santonicum L., Achillea } \\
\text { setacea Waldst. \& Kit. }\end{array}$ & 7.398344 \\
\hline $\begin{array}{l}\text { Open alkali } \\
\text { grassland }\end{array}$ & $\begin{array}{l}\text { Camphorosmetum } \\
\text { annuae, Puccinellietum } \\
\text { limosae }\end{array}$ & $\begin{array}{l}\text { high salt content close to or even on } \\
\text { the soil surface, halophyte species }\end{array}$ & $\begin{array}{l}\text { Camphorosma annua } \\
\text { Pall., Puccinella limosa } \\
\text { (Schur) Holmb. }\end{array}$ & 2.620432 \\
\hline $\begin{array}{l}\text { Alkali } \\
\text { meadow }\end{array}$ & $\begin{array}{l}\text { Agrostio stoloniferae- } \\
\text { Alopecuretum pratensis, } \\
\text { Beckmannietum }\end{array}$ & $\begin{array}{l}\text { tall grass, high ground water level, } \\
\text { low to moderate salt content in the } \\
\text { soil, surface water from spring to } \\
\text { early summer }\end{array}$ & $\begin{array}{l}\text { Alopecurus pratensis L., } \\
\text { Agropyron repens (L.) } \\
\text { Gould, Beckmannia eruci- } \\
\text { formis }(\mathrm{L} .) \text { Host }\end{array}$ & 10.154303 \\
\hline Loess steppe & $\begin{array}{l}\text { Salvio nemorosae- } \\
\text { Festucetum rupicolae }\end{array}$ & $\begin{array}{l}\text { high fertility humus rich soil, mono- } \\
\text { cot and forb species }\end{array}$ & $\begin{array}{l}\text { Salvia pratensis L., S. } \\
\text { nemorosa } \text { L., Festuca } \\
\text { rupicola } \text { Heuff. }\end{array}$ & 0.156431 \\
\hline
\end{tabular}


In 2000, with the help of aerial photographs and field observations, these different habitat types and areas (i.e. polygons) were recorded and shape files were created using the ArcMap 10.1 program. Each polygon of the attributed table contains one identification code for each of the eight habitats. We calculated the area of each habitat with the help of the ArcMap 10.1 program. The Pentezug Reserve is surrounded by a three-lined electric fence. Inside the area, horses and cattle can move freely between habitat types. Other wild animals, such as red fox (Vulpes vulpes Linnaeus, 1758), roe deer (Capreolus capreolus Linnaeus, 1758) and wild boar (Sus scrofa Linnaeus, 1758) can cross the fence. Surplus food or water was not offered except occasionally in winter and any human intervention (such as herding and mowing) was banned.

Przewalski's horse and cattle populations in the Pentezug Reserve

The founders of the horse population were selected by the coordinator of the European Endangered Species Programmes (EEP) to create the widest genetic base. The coordinator uses the studbook data (which contains parentage, location, birth, and other important data on the horses) to calculate the mean kinship and genetic diversity of the horses and create a viable population with the help of PMX 0.1 software. According to the advice of the EEP coordinator, we imported 31 horses and exported 59 horses between 1997 and 2018. Przewalski horses are not marked by branding or by chips. However, most individuals are recognised by the HNP staff based on their gender, age, special marks/characters, and the harem they belong to. The marks/characters include coat colour, stripes on the legs, shoulder crosses, cowlick positions, and other special features, such as double shoulder crosses or missing eartips. The horses were identified and counted regularly (every month, if possible) in the field. Members of bachelor groups are counted regularly, but they have not been recognised individually since 2008. Cattle founders arrived from different Hungarian, German, and Austrian zoological gardens and private gardens. The first cattle arrived at the reserve in 1999 and a total of 47 cattle arrived up until 2015. Cattle were marked with eartags since 2007 and counted once a year. However, before 2007 they were recognised with special characteristics individually and counted monthly just like the horses. We recorded births, deaths, imports, and exports for both the horses and cattle. In this way, we could calculate the number of horses and cattle at the end of every year and use this number to illustrate the yearly changes in the Pentezug Reserve.

Recognition and registration of horses in the Pentezug Reserve

Horses are registered in three databases, (1) a photo catalogue, (2) a group composition list, and (3) a DNA database. The photo catalogue consists of winter and summer portraits, summer and winter coats on both sides, and the back side of the animal. The group composition list consists of the positions of horses in different groups. The positions are recorded monthly from the beginning of the project with the exception of the years between 2008 and 2011, when there were only 1-4 observations annually. The genetic database of our horses is in the Davis Laboratory (Veterinary Genetics Laboratory, California, USA). We sampled each imported horse and all foals at the age of 1-2 year using a pneumatic rifle (operating with $\mathrm{CO}_{2}$ ) and special biopsy needles (PneuDart and DanInject). In this way, small amounts of skin or biopsy samples can be taken without tranquilising animals. If we cannot identify a horse, we take a repeat sample and the Davis Laboratory can identify the horse in question.

\section{Analysis of habitat use data}

We recorded 258 and 291 GPS data in 20042006 and in 2013-2014, respectively. We collected data once a day at the most and transferred data to two Excel databases. We made shape files from the GPS Excel files in the ArcMap 10.1 program for both periods. We integrated these GPS shape files and a habitat map shape file using the ArcMap 10.1 program. In this manner, every GPS point had a habitat identification number. We calculated how many times horses stayed in different habitats in both periods and seasonally. Habitat preference was evaluated by comparing the proportion of habitat (relative to the whole reserve area) and the proportion of time horses spent in the given habitat (compared to all observation). We checked the seasonal changes in the usage of the three largest habitats by comparing the proportion of time the animal spent in one habitat in one season and the time they spent in all habitats in the given season.

\section{Monitoring and analysis of activity data}

We differentiated eight activity types (Table 2) during our study based on the work of Boyd \& Houpt (1994). We recorded the activity of ten females in two harem groups every $2 \mathrm{~min}$. in 20082009 and 90 females in 28 harem groups every 4 
min. in 2013-2014 using a scan sampling method during daylight hours. The sampling lasted for 16 minutes and for $60 \mathrm{~min}$. in 2008-2009 and in 20132014 , respectively. We compared the activity percentage by calculating the ratio of the activity type to all recorded activities in the two periods. We examined the seasonal differences among activity types in 2013-2014 by calculating the proportion of time animals spent at a given activity compared to all activities in a season. We compared the three most remarkable activity types seasonally. Data visualisation and Kruskal-Wallis statistical tests were carried out using GraphPad Prism software.

\section{Body condition scores}

The body condition records were based on visual estimation (Rudman \& Keiper, 1991). The body condition was scored by checking the hind quarter of the horse and giving a score between 0 (very bad condition) and 5 (very good condition). We collected body condition scores of 50 horses and 90 horses in 2005 and 2018, respectively. We used binoculars and went as close as possible $(20-40 \mathrm{~m})$ to the given animal and waited till we could see the bottom symmetrically. Each animal had one score between July and October in each year. Five groups of horses were classified based on age, sex, and position in the social structure. (1) Bachelors: members of the bachelor group, either males who left natal groups and do not have a harem yet or former harem stallions. (2) Harem stallions: owners of a harem at the time of scoring. (3) Adult females: females who left natal groups. (4) Young males: still in natal groups. (5) Young females: still in natal groups. We compared the data of each group for the two time periods. We only used data where a minimum of five records were collected in both years. In this way, we could compare the data of the harem stallion group $(\mathrm{n}=5, \mathrm{n}=16)$, the adult female group $(\mathrm{n}=21$, $n=60)$, and the young male group $(n=9, n=26)$. We used Mann-Whitney tests to examine whether the groups were different in the two time periods. Data visualisation and statistical tests were carried out using GraphPad Prism software.

\section{Results}

\section{Population changes}

Since 1997, cattle and horse populations have grown rapidly in the area (Fig. 1). The total number of animals was highest in $2017(\mathrm{n}=950)$ and the population density reached 38.8 animals per $\mathrm{km}^{2}$. Within one year the total number of animals dropped by $33 \%$ when the intensive decrease in the number involved both cattle and horses. The number of cattle was 400 at the end of 2018. The total number of calves was 1135 and 738 cattle were sold or died in the history of the Pentezug Reserve. The cattle population grew constantly until 2010 and stagnated for three periods (2010-2012, 2013-2014, 2016-2017). The robust decrease in the cattle population after 2017 was due to human intervention (transportation to other areas or to slaughter-houses). The cattle population consisted of mostly adult cows and their offspring, only two breeding bulls were temporarily transported to the area since 2007. At the end of 2018, the horse population consisted of 280 animals. Approximately 259 animals died between 1997 and 2018 and 567 foals were born. The horse population was increasing until 2015. Between 2015 and 2017, the population grew slower due to human interventions (transports and contraception treatment). In 2018 there was a massive loss because the cold spring devastated many weak individuals.

Table 2. Description of activity types

\begin{tabular}{|c|c|}
\hline Activity type & Description \\
\hline Grazing & $\begin{array}{l}\text { When an animal eats grass, its head lowered down to the ground. Either standing or slowly } \\
\text { walking in the meantime. }\end{array}$ \\
\hline Resting & An animal is standing, ears are usually lateral, or lying on the ground. \\
\hline Moving & $\begin{array}{l}\text { An animal is walking without grazing, can be short (few steps) or long (wandering). An animal } \\
\text { is running. }\end{array}$ \\
\hline Alert & An animal is standing straight, looking to one direction, its ears are turned to the direction. \\
\hline Interaction & An animal has friendly or not friendly contact with another one. \\
\hline Comfort & $\begin{array}{l}\text { An animal is scratching itself on something, scratching itself with its teeth, rolling on the } \\
\text { ground. }\end{array}$ \\
\hline Other & $\begin{array}{l}\text { Special activity types that could not fit in the previous six, such as drinking, urinating, defecat- } \\
\text { ing, chewing, etc. Usually, a small number of events compared to the whole time budget. }\end{array}$ \\
\hline Undetermined & When an animal was not seen during the sampling period \\
\hline
\end{tabular}




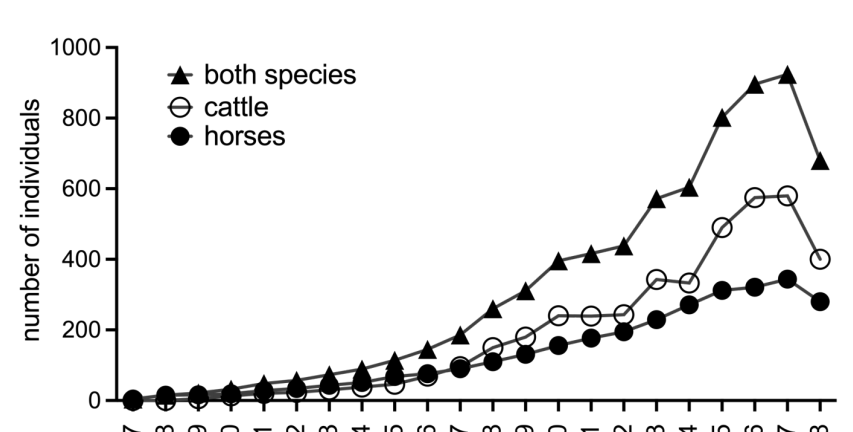

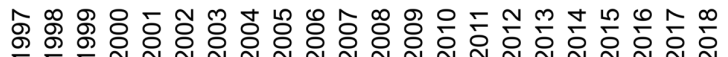

Fig. 1. Number of horses and cattle between 1997 and 2018 in the Pentezug Reserve, Hortobágyi National Park, Hungary.

\section{Habitat use of Przewalski horses}

The three most typical habitats in Pentezug Reserve are the alkali grassland, open alkali steppe, and alkali meadow (Fig. 2A,B). These habitats together cover approximately $85 \%$ of the total area. Horses spent most of their time in these habitats irrespective of the year of observation (either 2004-2006 or 2013-2014). Forest and loess steppe patches were hardly used in both periods (Fig. 2B). A comparison of the proportion of a given habitat and the proportion of time horses spent in the habitat revealed their habitat preference (Fig. 2B). When the proportion of habitat was higher than the proportion of time spent there, then the habitat was not preferred. Horses did not prefer the alkali meadow and salt marsh, while they preferred the alkali steppe, alkali grassland, and weed. Interestingly, the weed habitat was highly preferred in 2004-2006, partly because this habitat could be found around small houses or former stables that could provide shelter for horses against the sun and wind, but they were broken down by 2013 . Also, a high nitrogen and phosphorous content can be attractive for horses.
A

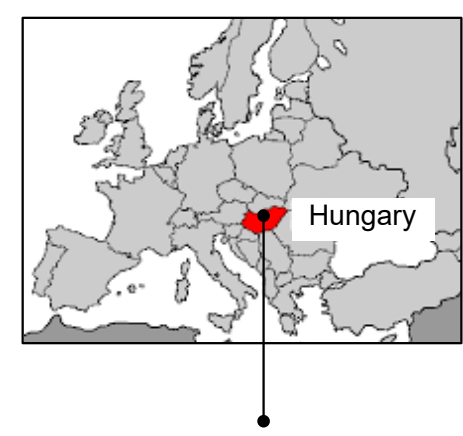

Pentezug Reserve Hortobagy National Park

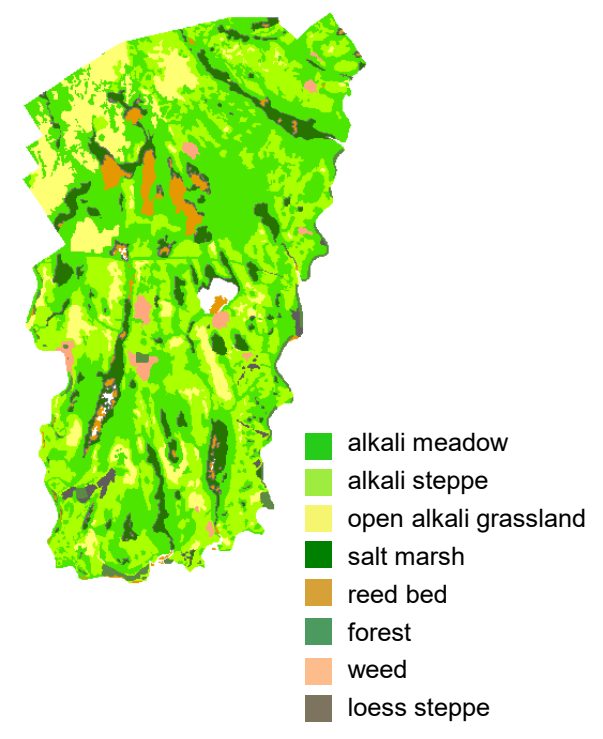

B

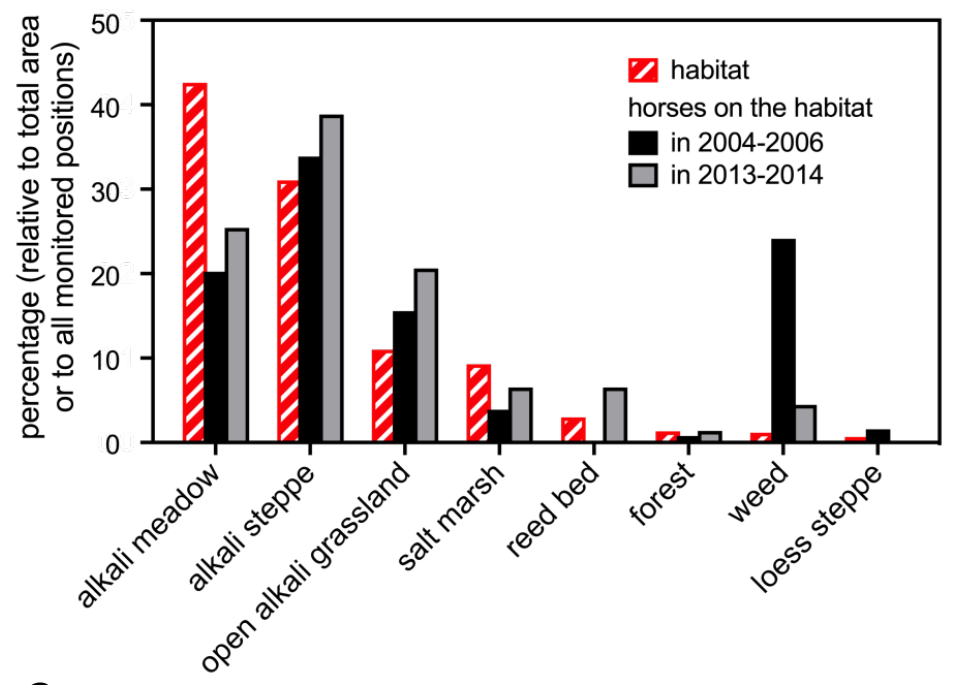

C

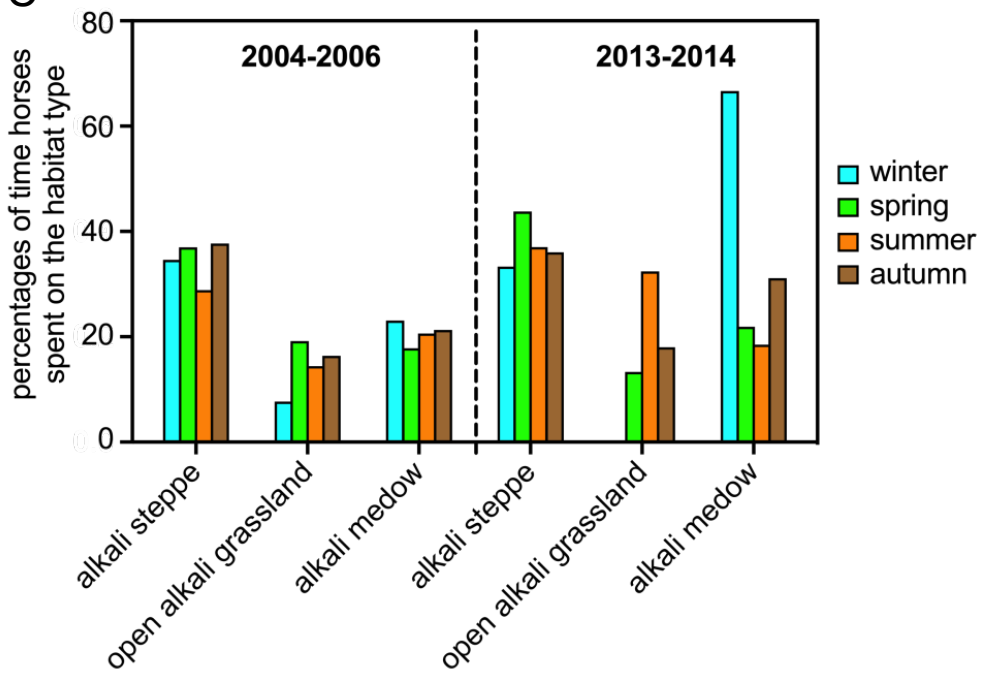

Fig. 2. Habitats of Pentezug Reserve and habitat use of Przewalski's horses. (A) Habitats of the reserve as determined by botanists of the Hortobágyi National Park in 2000. The areas are colour coded as indicated. (B) The proportion of habitats and time horses spent on the given habitat are shown together. The proportion of time horses spent on the habitats was determined in two periods based on GPS data. (C) The proportions of time horses spent in the habitats seasonally in two periods. Results are shown only for the three largest habitats. 
We also investigated whether habitat use exhibited seasonal changes in the two periods. Most of the habitats were used similarly in 2004-2006. Only open alkali grassland was used less frequently in winter. In 2013-2014, we detected seasonal differences in the case of two habitats. Animals spent more time on open alkali grassland in summer than in spring or autumn and they did not use the open alkali grassland in winter. Also, horses could be found on alkali meadows much more in the winter than in the other two habitat types (Fig. 2C). These data suggest that, in 2013-2014, the open alkali grassland was not used.

\section{Activity of horses}

We recorded 2482 and 5995 activity events in 2008-2009 and in 2013-2014, respectively. In both monitored years, we found that three activity types, namely grazing, resting, and moving, covered $90 \%$ of the yearly activity (Fig. 3A). The ratio of these activities did not change from 2008 to 2013. The only remarkable changes were in the undetected activities, which increased in 2013 compared to 2008 (Fig. 3A) because monitoring groups with more members resulted in more undetected horses. Seasonal activity ratios in 2013-2014 demonstrate that grazing is the most common activity in all seasons.
However, horses spent almost the same amount of time resting as grazing in spring and summer (Fig. 3B). Similar seasonal changes can be found in 2008 2009 (data not shown). Grazing, resting, and moving were significantly different seasonally (Fig. 3C). Horses spent more time grazing in autumn and winter than in spring and summer. On the other hand, they rested much more in warmer seasons than in colder ones. Horses spent almost the same amount of time moving in the spring, summer, and autumn, but much less in the winter.

\section{Changes in body condition}

The condition scores of adult females and young males decreased from 2005 to 2018 (Mann-Whitney test $\mathrm{p}<0.0001)$. Female scores varied between 3-4.5 and 2.5-4.5 in 2005 and in 2018, respectively. Scores of young males varied between 3.5-4.0 and 2.5-4.0 in 2005 and 2018, respectively. The scores for harem stallions did not differ significantly between the two time periods (Mann-Whitney test $p=0.87)$ and the more animals we could score, the more variable results we got. The scores of bachelors and young females could not be compared, because of inadequate data ( $\mathrm{n}=3$ for bachelors in 2018 and $n=3$ for young females in 2005).

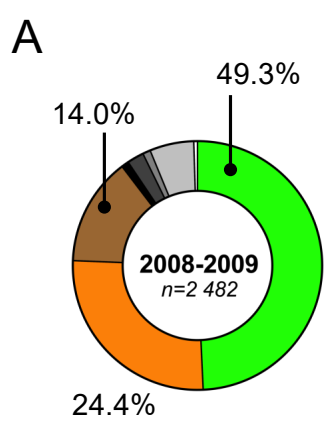

C

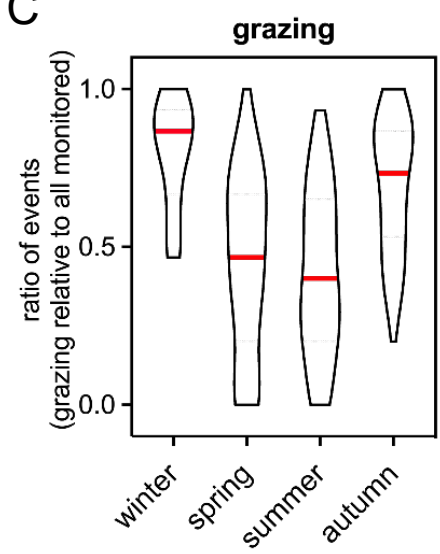

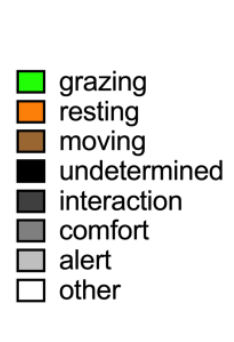

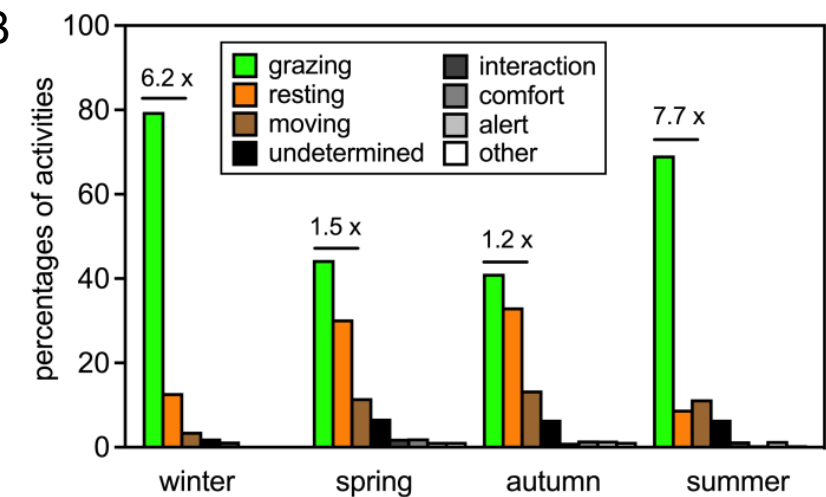

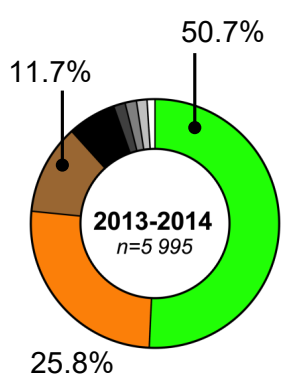

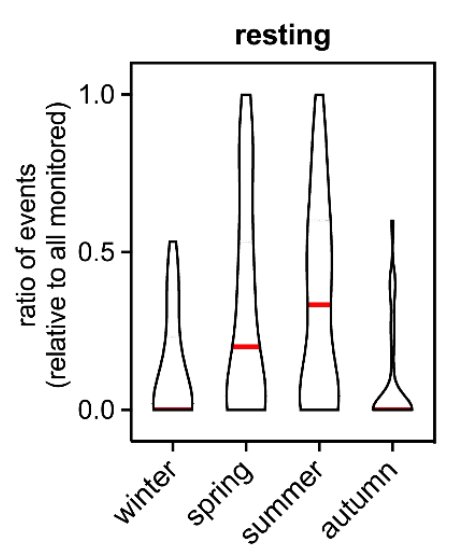

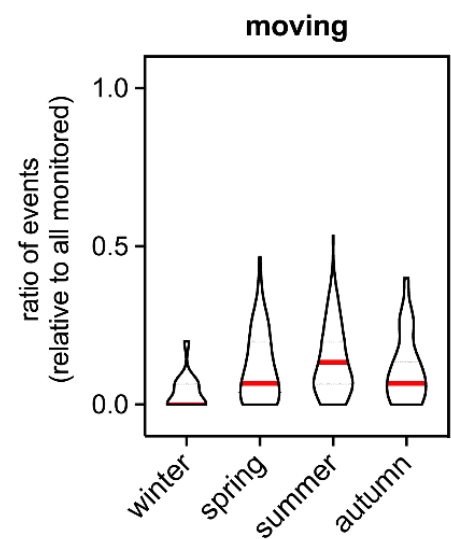

Fig. 3. Seasonal changes in the activity of Przewalski's horses in Pentezug Reserve. (A) The proportion of activities in two periods of time (2008-2009 and 2013-2014), both covering 12 months, are shown. (B) The proportion of the activities for four seasons is shown separately. The ratio of the two most frequent activities (grazing and resting) is shown for each season. (C) The density of the data at different values for four seasons and three activities is shown on violin plots. The medians are indicated in red. The comparison of four data sets revealed significant changes $(\mathrm{p}<0.001)$ according to Kruskal-Wallis tests in all three activities. 


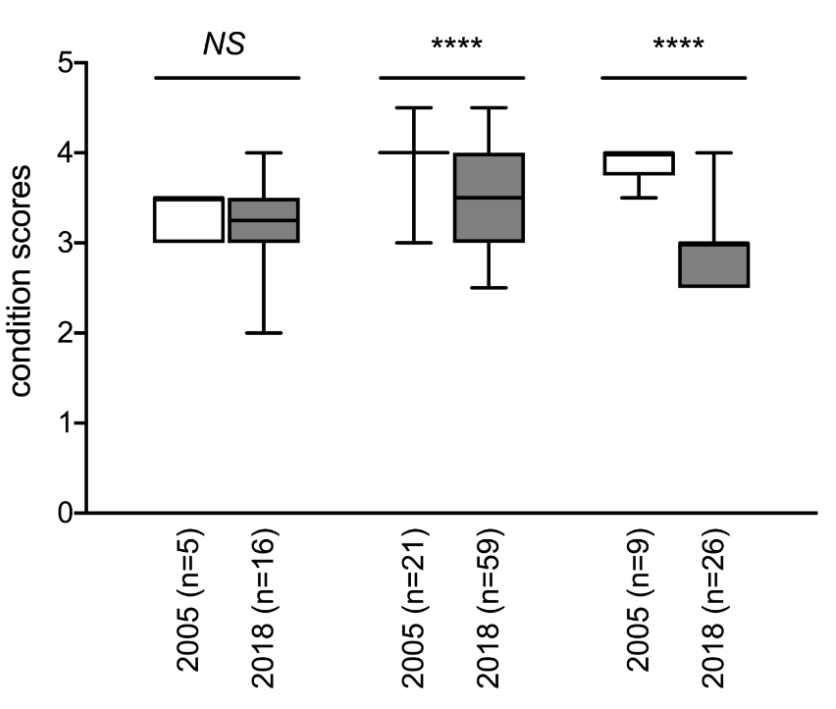

harem stallions adult females young males

Fig. 4. Condition scores of Przewalski's horses in Pentezug Reserve. The number of monitored individuals is shown in brackets. The condition scores obtained from two years were compared separately for each group using Mann-Whitney statistical tests (NS - not significant; $* * * *-p<0.0001$ ).

\section{Discussion}

The number of Przewalski's horses and reconstructed aurochs has remarkably increased in the Pentezug Reserve since launching the project. We can see similar phenomena in other areas where grazers were introduced and the former apex predator was missing (Caughley, 1981; Coulson et al., 2001). Since these two species compete for grasslands to a certain degree (Duncan et al., 1990; Menard et al., 2002), it is important to consider the cattle population when examining the horses' behaviour or activities. In 2007, the number of cattle started to grow dramatically. Two different strategies were selected to control the population growth of the two species. Horses were treated as wild animals but cattle were caught once a year (in winter) for the purpose of population regulation. The thresholds in the cattle population graph show all the years when we managed to sell more animals compared to how many were born and could control the population growth. Horses, on the other hand, were not caught easily and the only way to treat them is when tranquilised one by one. Furthermore, the Przewalski's horse is a rare species and categorised as endangered in the IUCN Red List (Walzer et al., 2012). For this reason, controlling the population growth is a delicate question. We could cull animals with fatal injuries or the ones suffering on the edge of death. However, we have to ask individual permission from the local au- thorities, where all our animals are registered. Immunocontraception is an option for management of large horse populations (Kirkpatrick et al., 1990). In 2013, following the recommendation of the EEP coordinator of Przewalski's horses, we decided to use Pig Zona Pellucida (PZP) immunocontraception (Turner et al., 2002) to slow down the population growth. In 2015 , the population growth did slow down as an effect of this treatment. Nevertheless, we had an enormous loss of horses (40-50 horses) and cattle (20-30 cows) in 2018, most likely due to a combination of a very cold spring (snow and 15 degrees below zero) in March, a massive drought in 2016-2017, and a large number of both cattle and horses. This phenomenon can also be observed in areas occupied by feral horses (Scorolli et al., 2006). We decided to reduce the number of both species as soon as possible. We sold more cattle compared to the number born, resulting in a fast reduction in the animal population. We are planning to increase the number of PZP-treated female horses.

We assume that the changes in number will not only alter the vegetation, but also the behaviour of the Przewalski's horse population. Horses prefer a habitat with grass species dominated by Festuca pseudovina Hack. ex Wiesb. This species can grow even if the temperature is below zero providing small but continuous amounts of green plant parts that are important for horses when choosing habitat (Duncan, 1983; King, 2002). Open alkali grasslands are attractive in summer in higher animal density, when horses destroy its vegetation by trampling and create dust baths to avoid insects. As a consequence, these habitats cannot provide food in winter. On the other hand, grass species on alkali meadow grow and dry quickly but provide quite a large amount of food in winter, when other habitats cannot offer enough food because of the growing animal density (Beest et al., 2014). As a consequence of their preference for weed habitat, horses prove to be a good tool for maintaining the natural grassland vegetation and they can eliminate small amounts of weed vegetation by trampling or feeding on it.

Activity types for Przewalski's horses in Hortobagy are similar to Przewalski's horses or feral horses in other areas. Grazing takes up the largest part of their time and they rest more and graze less in the summer than in winter (Boyd et al., 1988; Duncan, 1992; Boyd \& Bandi, 2002; 
Souris et al., 2007). Berger at al. (1999) found a similar pattern, although they recorded horse movement even during the night. Horses have to increase food intake during winter, when the food is less nutritious (Berger et al., 1999). We expected that the growing population and decreasing amount of food in the area would alter the grazing-rest ratio. This ratio, however, did not change in the two periods, which suggests the population number did not alter the activity percentage in Pentezug.

If we compare the body condition in 2005 and in 2018, we can conclude that the condition of most horses greatly decreased probably because of the larger density and less available food (Rudman \& Keiper, 1991). Environmental effects have more impact on young horses while they are still growing and cannot collect fat deposits. The harem stallions' physical condition did not change over the years, but the data show a high variability for this group. Harem stallions go through different stages when owning a harem. In the beginning, they have to put a lot of effort into protecting the harem and keeping the new members together. Also, when they are old or injured their physical condition quickly decreases and they often lose the harem.

\section{Conclusions}

We demonstrate that the Pentezug Reserve has been an adequate area for both Przewalski's horses and reconstructed aurochs for the last 22 years. To avoid overpopulation of the area, human interventions (birth control, transport, etc.) are essential. Monitoring the habitat use and body conditions of Przewalski's horses are also important because changes in these characteristics could indicate the necessity for human interventions.

\section{References}

Berger A., Scheibe K.M., Eichhorn K., Scheibe A., Streich J. 1999. Diurnal and ultradian rhythms of behaviour in a mare group of Przewalski horse (Equus ferus przewalskii), measured through one year under semi-reserve conditions. Applied Animal Behaviour Science 64(1): 1-17. DOI: 10.1016/S0168-1591(99)00026-X

Beest F.M., Uzal A., Vander Wal E., Laforge M.P., Contasti A.L., Colville D., McLoughlin P.D. 2014. Increasing density leads to generalization in both coarse-grained habitat selection and fine-grained resource selection in a large mammal. Journal of Animal Ecology 83(1): 147-156. DOI: 10.1111/1365-2656.12115
Bouman I., Bouman J. 1994. The history of Przewalski's horse. In: L. Boyd, K. Houpt (Eds.): Przewalski's horse. The history and biology of an endangered species. Albany, New York: State University of New York Press. P. 5-38.

Boyd L.E., Carbonaro D.A., Houpt K.A. 1988. The 24-hour time budget of Przewalski horses. Applied Animal Behaviour Science 21(1-2): 5-17. DOI: 10.1016/01681591(88)90098-6

Boyd L., Houpt K.A. 1994. Activity patterns. In: L. Boyd, K. Houpt (Eds.): Przewalski's horse. The history and biology of an endangered species. Albany, New York: State University of New York Press. P. 195-254.

Boyd L., Bandi N. 2002. Reintroduction of takhi, Equus ferus przewalskii, to Hustai National Park, Mongolia: time budget and synchrony of activity pre-and post-release. Applied Animal Behaviour Science 78(2-4): 87-102. DOI: 10.1016/S0168-1591(02)00088-6

Caughley G. 1981. Overpopulation. In: P.A. Jewell, S. Holt (Eds): Problems in Management of Locally Abundant Wild Mammals. New York: Academic Press. P. 91-118.

Coulson T., Catchpole E.A., Albon S.D., Morgan B.J.T., Pemberton J.M., Clutton-Brock T.H., Crawley M.J., Grenfell B.T. 2001. Age, sex, density, winter weather, and population crashes in Soay sheep. Science 292(5521): 1528-1531. DOI: 10.1126/science.292.5521.1528

Deák B., Valkó O., Alexander C., Mücke W., Kania A., Tamás J., Heilmeier H. 2014a. Fine-scale vertical position as an indicator of vegetation in alkali grasslands - Case study based on remotely sensed data. Flora - Morphology, Distribution, Functional Ecology of Plants 209(12): 693-697. DOI: 10.1016/j.flora.2014.09.005

Deák B., Valkó O., Török P., Tóthmérész B. 2014b. Solonetz meadow vegetation (Beckmannion eruciformis) in East-Hungary - an alliance driven by moisture and salinity. Tuexenia 34(1): 187-203. DOI: 10.14471/2014.34.004

Deák B., Valkó O., Tóthmérész B., Török P. 2014c. Alkali marshes of Central-Europe: Ecology, management and nature conservation. In: Hong-bo Sh. (Ed.): Salt marshes: ecosystem, vegetation and restoration strategies. New York: Nova Science Publishers. P. 1-11.

Duncan P. 1983. Determinants of the use of habitat by horses in a Mediterranean wetland. Journal of Animal Ecology 52(1): 93-109. DOI: 10.2307/4590

Duncan P. 1992. Horses and grasses: the nutritional ecology of equids and their impact on the Camargue. NewYork: Springer Science \& Business Media. 287 p.

Duncan P., Foose T.J., Gordon I.J., Gakahu C.G., Lloyd M. 1990. Comparative nutrient extraction from forages by grazing bovids and equids: a test of the nutritional model of equid/bovid competition and coexistence. Oecologia 84(3): 411-418. DOI: 10.1007/BF00329768 
Janis C. 1976. The evolutionary strategy of the Equidae and the origins of rumen and cecal digestion. Evolution 30(4): 757-774. DOI: 10.1111/j.15585646.1976.tb00957.x

King S.R.B. 2002. Home range and habitat use of free-ranging Przewalski horses at Hustai National Park, Mongolia. Applied Animal Behaviour Science 78(2-4): 103 113. DOI: 10.1016/S0168-1591(02)00087-4

King S.R. 2005. Extinct in the Wild to Endangered: the history of Przewalski's horse (Equus ferus przewalskii) and its future conservation. Mongolian Journal of Biological Sciences 3(2): 37-41.

Kirkpatrick J.F., Liu I.K.M., Turner J.W. 1990. Remotelydelivered immunocontraception in feral horses. Wildlife Society Bulletin 18(3): 326-330.

Lorimer J., Driessen C. 2013. Bovine biopolitics and the promise of monsters in the rewilding of Heck cattle. Geoforum 48: 249-259. DOI: 10.1016/j.geoforum.2011.09.002

Menard C., Duncan P., Fleurance G., Georges J.Y., Lila M. 2002. Comparative foraging and nutrition of horses and cattle in European wetlands. Journal of Applied Ecology 39(1): 120-133. DOI: 10.1046/j.13652664.2002.00693.x

Molnár Z. 2014. Perception and management of spatiotemporal pasture heterogeneity by Hungarian herders. Rangeland Ecology \& Management 67(2): 107-118. DOI: 10.2111/REM-D-13-00082.1

Rudman R., Keiper R.R. 1991. The body condition of feral ponies on Assateague Island. Equine Veterinary Journal 23(6): 453-456. DOI: 10.1111/j.20423306.1991.tb03760.x

Scorolli A.L., Lopez Cazorla A.C., Tejera L.A. 2006. Unusual mass mortality of feral horses during a violent rainstorm in Parque Provincial Tornquist, Argentina. Mastozoologia Neotropical 13(2): 255-258.

Sommer R.S., Benecke N., Lxugas L., Nelle O., Schmцlcke U. 2011. Holocene survival of the wild horse in Europe: a matter of open landscape? Journal of Quaternary Science 26(8): 805-812. DOI: 10.1002/jqs.1509

Souris A.C., Kaczensky P., Julliard R., Walzer C. 2007. Time budget-, behavioral synchrony- and body score development of a newly released Przewalski's horse group Equus ferus przewalskii, in the Great Gobi B strictly protected area in SW Mongolia. Applied Animal Behaviour Science 107(3-4): 307-321. DOI: 10.1016/j.applanim.2006.09.023

Török P., Kapocsi I., Deák B. 2012. Conservation and management of alkali grass-land biodiversity in CentralEurope. In: W.J. Zhang (Ed.): Grasslands: Types, Biodiversity and Impacts. New York: Nova Science Publishers Inc. P. 109-118.

Turner J.J., Liu I.K., Flanagan D.R., Bynum K.S., Rutberg A.T. 2002. Porcine zona pellucida (PZP) immunocontraception of wild horses (Equus caballus) in Nevada: a 10 year study. Reproduction (Cambridge, England) Supplement 60: 177-186.

Vörös I. 1987. Large Mammalian Fauna Changes during the late Upper Pleistocene and Early Holocene Times in the Carpathian Basin. In: M. Pécsi (Ed.): Pleistocene environment in Hungary. Budapest: Geographical Research Institute Hungarian Academy of Sciences. P. 81-101.

Wakefield S., Knowles J., Zimmermann W., Van Dierendonck M. 2002. Status and action plan for the Przewalski's horse (Equus ferus przewalskii). In: P.D. Moehlman (Ed.): Equids: Zebras, Asses, and Horses: Status Survey and Conservation Action Plan. Gland, Switzerland and Cambridge, UK: IUCN/SSC Equid Specialist Group. P. 82-92.

Walzer C., Kaczensky P., Zimmermann W., Stauffer C. 2012. Przewalski's horse reintroduction to Mongolia: status and outlook. WAZA Magazine 13: 3-6.

Xia C., Cao J., Zhang H., Gao X., Yang W., Blank D. 2014. Reintroduction of Przewalski's horse (Equus ferus przewalskii) in Xinjiang, China: the status and experience. Biological Conservation 177: 142-147. DOI: 10.1016/j.biocon.2014.06.021 
АНАЛИЗ ПАРАМЕТРОВ ИСПОЛЬЗОВАНИЯ ТЕРРИТОРИИ, АКТИВНОСТИ И ФИЗИЧЕСКОГО СОСТОЯНИЯ ЛОШАДЕЙ ПРЖЕВАЛЬСКОГО В НАЦИОНАЛЬНОМ ПАРКЕ ХОРТОБАДЬ, ВЕНГРИЯ

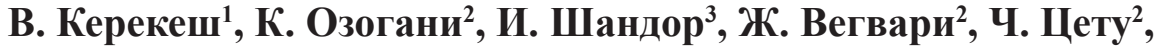 \\ Б. Ниру ${ }^{4}$, Т. Сабадош ${ }^{1}$, Л. Силеш ${ }^{2}$, 3. Барта ${ }^{2}$ \\ ${ }^{1}$ Администрация Национального парка Хортобадь, Венгрия \\ e-mail:kerekesviola@hnp.hu \\ ${ }^{2}$ Дебреиенский университет, Венгрия \\ e-mail:katalin.ozogany@gmail.com,szelesl@med.unideb.hu,barta.zoltan@science.unideb.hu \\ ${ }^{3}$ Будапештский зоопарк и ботанический сад, Венгрия \\ e-mail: afiumvet@gmail.com \\ ${ }^{4}$ Правительство округа Хайду-Бихар, Венгрия \\ e-mail:nyiro.bettina@hajdu.gov.hu
}

Популяция лошади Пржевальского (Equus ferus przewalskii) был основана в полурезервате Пентезуг в Национальном парке Хортобадь в 1997 г. Кроме лошадей Пржевальского, там также разводят восстанов-

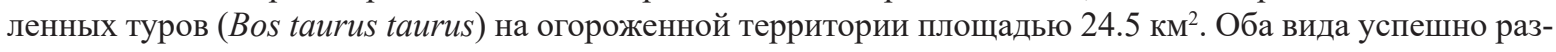
множились в степном заповеднике, некогда бывшим родиной их далеких предков. Количество крупных травоядных росло так быстро, что для восстановленных туров и лошадей пришлось применять разные стратегии контроля популяции в 2007 и 2013 гг, соответственно. На протяжении 22 лет проводился постоянный мониторинг активности, использования территории и физического состояния лошадей Пржевальского. Мы обнаружили сезонные изменения в активности лошадей, но соотношение основных типов активности были схожи в два разных периода времени. Напротив, были выявлены значительные различия в использовании территории и физическом состоянием лошадей в ранние и поздние годы проекта. Имеется в виду, что лошади были вынуждены использовать непривлекательные районы, и их состояние ухудшалось по мере увеличения плотности популяций крупных травоядных. Во время холодной весны 2018 г. произошла массовая гибель как лошадей, так и туров. Исследования показали, что ограниченные запасы кормов могут привести к изменениям в использовании среды обитания и/или ухудшению физического состояния, увеличению смертности при экстремальных погодных условиях. Таким образом, строгие меры контроля над рождаемостью лошадей Пржевальского должны применяться в популяциях с высокой численностью, и необходимо контролировать использование территории и физическое состояние животных, чтобы находить баланс между численностью популяции и емкостью угодий.

Ключевые слова: Bos taurus taurus, Equus ferus przewalskii, восстановленный тур, емкость угодий, заповедник Пентезуг, контроль численности, крупные травоядные, полурезерват 